\title{
Using the Community-Based Participatory Research (CBPR) Approach in Childhood Obesity Prevention
}

\author{
Janavi Kumar ${ }^{1}$, Tandalayo Kidd ${ }^{1}{ }^{*},{ }^{*}$ Yijing Li ${ }^{1}$, Erika Lindshield ${ }^{1}$, Nancy Muturi ${ }^{2}$ and \\ Koushik Adhikari ${ }^{3}$ \\ ${ }^{1}$ Department of Human Nutrition, Kansas State University, Manhattan, KS 66502, USA \\ ${ }^{2}$ A.Q. Miller School of Journalism and Mass Communications, Kansas State University, Manhattan, KS \\ 66502, USA \\ ${ }^{3}$ University of Georgia, 0178 Melton Building, 1109 Experiment St, Griffin, GA 30223, USA
}

\begin{abstract}
Childhood and adolescent obesity has increased drastically in the past 30 years. While this is troubling, there is also evidence of large disparities among certain ethnic groups such as African American and Hispanic children and adolescents. The Community-Based Participatory Research (CBPR) Model emphasizes a collaborative, co-learning, mutually beneficial, and community-partnered approach to research. Unique aspects of this model include viewing community members as equal partners in non-hierarchical teams, working together in a strengths-based, action oriented research process. This review consists of an investigation of the CBPR approach, its important tenets, and why such an approach may be more effective for childhood and adolescent obesity intervention program development, especially in stratified communities.
\end{abstract}

Keywords: Childhood and adolescent obesity, Community-Based Participatory Research, community, engagement, health disparity.

\section{INTRODUCTION}

The growing rate of childhood overweight and obesity [1, 2] suggests a need for more effective obesity prevention programs. However, it is no longer sufficient to directly translate findings from highly controlled trials to real-world community interventions in diverse environments, since these controlled trials do not account for variability in culture, resources and organizations [3-5]. Research in the past decade had started to show how holistic, community-based approaches using local resources can pave the way for a future of effective public health interventions [6-9]. Childhood obesity is a complex problem with a complicated etiology. Thus, public health educators working with today's youth need to keep in mind the holistic components particular to the group of youth being studied [10].

Community-Based Participatory Research (CBPR) is a collaborative approach to research that includes equal contributions from community members, organizational representatives and researchers in all facets of the research process. The approach allows participants to share their expertise in order to enhance knowledge and develop interventions that benefit the whole community [11]. CBPR represents a paradigm shift in bridging the gap between science and practice,

*Address correspondence to this author at the Department of Human Nutrition, Kansas State University, 203 Justin Hall, Manhattan, KS 66502, USA; Tel: 785532-0154; Fax: 785-532-1678; E-mail: martan@ksu.edu

E-ISSN: $1929-4247 / 14$ by bringing in community engagement to improve health outcomes [12]. The CBPR model incorporates the following tenets: it is a mindset and a collaborative approach to a research topic defined by what is important to the community, it involves and utilizes talents and abilities of all partners, and has the goals of improving health outcomes, achieving social change, eliminating health disparities, while everything is done in a sustainable manner $[13,14]$. This review consists of an investigation of the CBPR approach, its important tenets, and why this approach is beneficial in informing researchers on intervention program development for stratified communities.

\section{RACIAL AND ETHNIC DISPARITIES IN CHILDHOOD AND ADOLESCENT OBESITY}

Racial and ethnic disparities are prominent in obesity prevalence among U.S. adolescent girls and boys. Although obesity rates have increased for boys and girls within each ethnic and racial group, there is a higher percentage of overweight and obesity in some ethnic subgroups such as African American and Mexican American children [2, 15, 16]. Figures 1 and 2 show that both African American and Hispanic children are more likely to be overweight than white nonHispanic children, but African American and lowerincome children have a higher incidence of obesity overall.

The main burden of childhood obesity has shifted from the high socio-economic strata (SES) to the low 


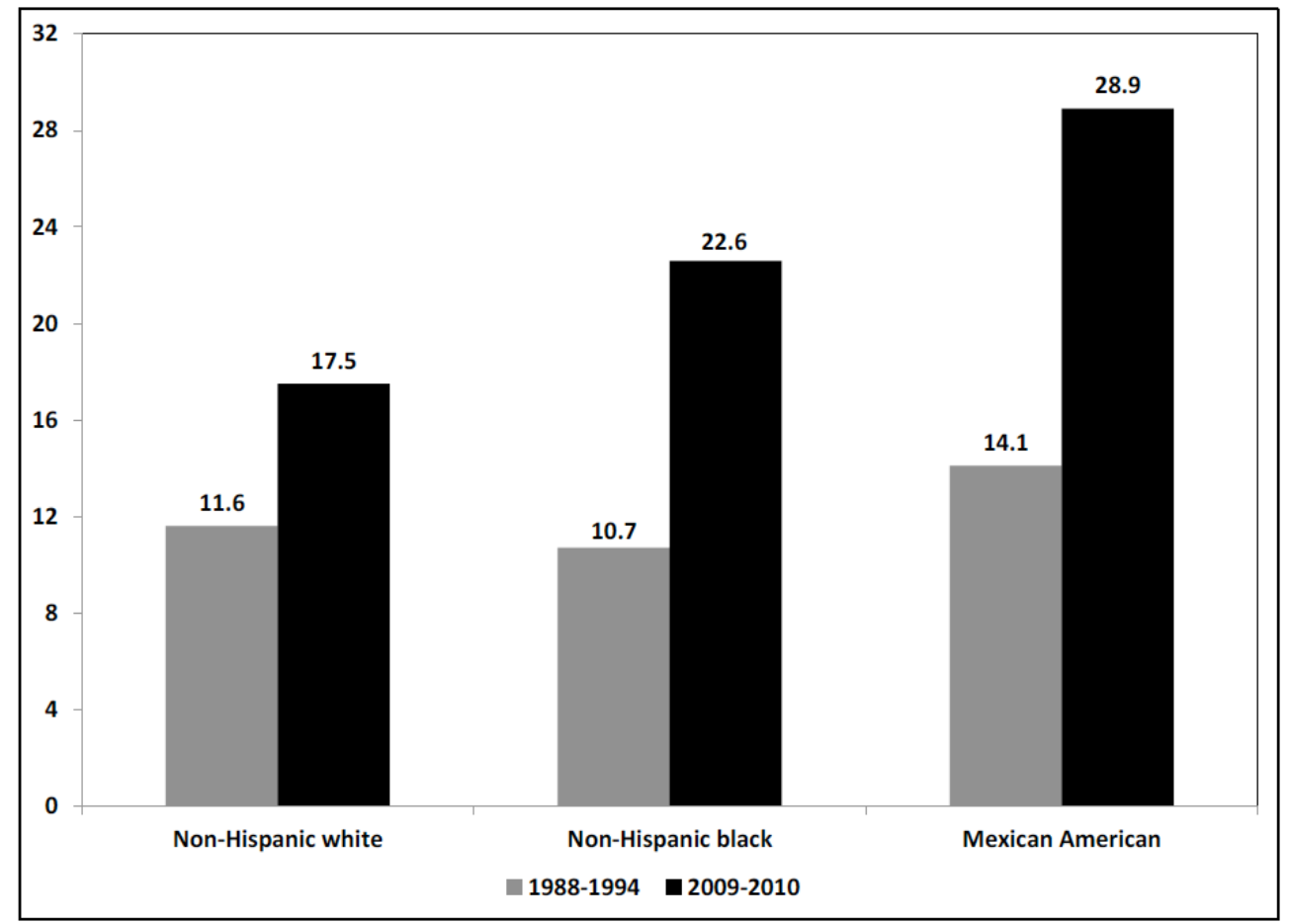

Figure 1: Prevalence of obesity among boys aged 12-19 years, by race and ethnicity: United States, 1988-1994 and 2009-2010, adapted from Fryar et al. [2].

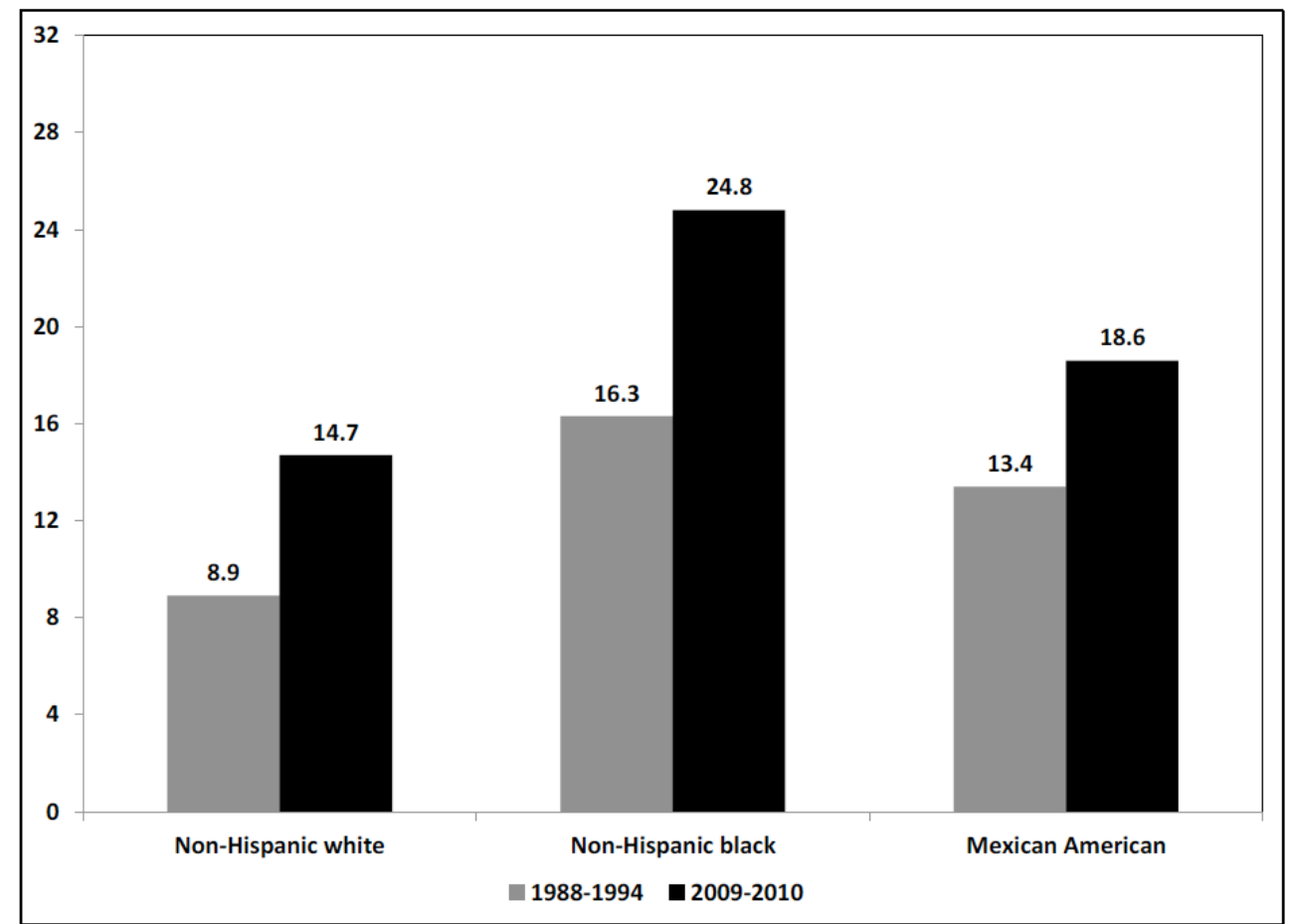

Figure 2: Prevalence of obesity among girls aged 12-19 years, by race and ethnicity: United States, 1988-1994 and 2009-2010, adapted from Fryar et al. [2].

SES strata [17]. The CBPR model is often carried out in predominantly low-income communities and communities of color because of the viability of this model to address health disparities experienced by these communities [11]. These disparities in obesity cannot be explained solely on few factors only. Their complex etiology is dependent on multiple variables and interactions between those variables. Researchers have found a link between built environments and children's physical activity. For instance the lack of 
sidewalks, long-distances to schools, and busy streets discourage children from walking or biking to schools [18]. CBPR has the ability to expand the reach of research to influence policies targeted toward ending disparities [12].

\section{Increased Consumption of Energy Dense Foods}

Darmon and Drewnowski recognized that lower income families are inclined to consume greater portions of high energy-dense foods [19]. The primary reason for this is these foods tend to be cheaper. Also, there seems to be a higher value placed on certain energy-dense foods because they are perceived as foods that people should be able to afford and enjoy [20]. If access to energy-dense foods high in fat and sugars had previously been low, such foods may be more highly consumed when available [15]. Dietary acculturation of certain ethnic groups may also influence consumption of energy-dense food [21].

The CBPR model has been used successfully in community-partnered programs to address healthy food availability in low-income communities concerned with food insecurity [22]. Ethnic minority populations usually trend toward a higher level of environmental and psychological stress, associated with racial discrimination, violence, economic stress, concerns about economic security and personal safety, and perceived inability to improve their or their children's life circumstances. Coping strategies that include the use of food (often, energy-dense foods) are not uncommon and this behavior of using food to relieve stress increases the risk of obesity and obesity-related diseases $[15,23]$.

\section{Education Level}

A common problem that exists in low-income and less educated people is lowered trust in the claims of scientific experts [24]. It is hypothesized that individuals who distrust science- based advice are more likely to be vulnerable to messages concerning dieting and "quick fixes", and this has shown to increase the risk of future obesity in adolescents [25]. Parents with lower education are hypothesized to be more vulnerable to food advertising that encourages consumption of "junk food" [26]. They are also more susceptible to underlying messages in entertainment programs which portray energy-dense foods in a positive way [27]. Lower education is also associated with lack of "lay knowledge", which makes nutrition education programs less comprehensible for people without higher education [28]. A very important tenant within the CBPR model is knowledge dissemination among both the community members and researchers involved in the project. Knowledge is gained and shared among all in an understandable and friendly way. Knowledge is not just something to be gained when working under the CBPR model, but it is acknowledged that ownership of that knowledge lies with the community [29].

\section{Lessened Physical Activity}

Low-income neighborhoods and environments tend to be unsafe due to a higher proportion of criminal activity. This results in reduced physical activity environments for children in these neighborhoods and communities [30]. Parents of lower-income families are more inclined to view their "work" as physical activity, and seek sedentary rest and relaxation whenever possible [15]. Limited access to sports facilities and clubs may also contribute to less exercise in low-SES youth [31].

The higher rates of obesity among ethnic minority and low-income children, when combined with the adverse health effects of childhood obesity, are likely to produce continued racial and economic differences in health outcomes. CBPR intervention components including community awareness campaigns, physical education enhancements, food service reform, and family outreach efforts have been observed favorable [32].

\section{ECOLOGICAL APPROACHES TO THE PROBLEM}

New research strategies involve addressing not only individual-level influences and choices that lead to energy imbalance, but also the complex systems occurring at the interpersonal, community, and governmental levels. This comprehensive perspective involves the use of ecological approaches as one of the best ways to work toward creative solutions.

Our environment has changed radically in the past few decades, and continues to evolve in many ways. The current day obesity epidemic is hypothesized to be the result of the development of an obesogenic environment that promotes a combination of increased food (energy-dense) consumption and decreased physical activity [33]. Individuals and families are not isolated entities; they live and function in the context of neighborhoods and communities. Hence, they must be studied in that context. Effective community-based 
programming efforts are required to reach high-risk families and individuals to prevent and control obesity given the shift towards an obesogenic environment. Environments are complex and there are multiple dimensions of influence on person-environment interactions within any given setting. Successful interventions consider the multiple levels or dimensions that interact with family and child behaviors. Ecological approaches, addressing the built environment in which a certain community lives, help in identifying points of influence for health promotion interventions [18, 34, 35]. Several principles from the socio-ecological model (SEM), as detailed by Stokols, serve as valuable guidelines for developing context-sensitive community based intervention programs [36].

The SEM is important to CBPR because it entails a community understanding of health and health behavior, and involves interdisciplinary approaches to interventions. Stokols states that it clarifies the complex relationships "among persons, groups, and their sociopolitical milieus" [36]. The SEM provides an excellent overarching framework for examining individual, organizational, and community factors in causes of childhood obesity [36, 37].

Krug et al. write on the various structure levels which need to be addressed in order to positively impact overweight and obesity. These include the individual level (biological factors, knowledge, attitudes, traits), interpersonal (family, friends, peers, social identity), organizational (schools, churches, regulations, policies), community (social networks, neighborhoods, coalitions/organizations), and societal level (local, state, federal policies and laws, economics, education) [38].

\section{PARADIGM SHIFT TO CBPR}

In the past, the field of public health has studied environmental and social determinants of health [39]. They also included public input in identifying and addressing public health problems [14]. Over time however, emphasis shifted from the former approach to the current one that stresses individual risk factors, and removes researchers and public health practitioners from the public and deems them as the health "experts" [40]. While the latter approach helps researchers gain more detailed and extensive information on individual level risk factors, it also has a huge drawback as it tends to obscure the contributions of social and environmental factors to health problems. This is most visible in the growing gap between the health status of rich and poor, white and non-white, urban and nonurban [40].

In the early nineties, researchers started to revive the focus on an ecological approach. This approach recognized that individuals are embedded within complex social, political and economic systems, and these shape behaviors and access to resources necessary for good health [40]. Greater focus has also been placed on the translation and integration of basic research in intervention development and applied research. Moreover, greater community involvement in the research and intervention processes, for instance, through partnerships between academic, communitybased organizations, etc. has been emphasized [39]. This is advantageous because it increases sensitivity to diversity, as well as competence in working within diverse cultures.

\section{Key Principles of CBPR}

The following are key elements of the CBPR approach of intervention development as adapted from Israel et al. [14]. It is important to remember that the degree to which the research can achieve one or more of these principles may largely vary; and this variation will depend on context, purpose, and participants involved in intervention development. CBPR will often result in an integration of the following elements:

- $\quad$ CBPR involves working with the community as a unit of identity.

- $\quad$ CBPR builds on strengths and resources within the community.

- CBPR involves collaborative and equal involvement of all partners in all phases of the research process.

- $\quad$ CPBR integrates knowledge for mutual benefit of all partners.

- $\quad$ CBPR attends to social inequalities through a colearning and empowering process.

- $\quad$ CBPR involves a cyclical and iterative process.

- $\quad$ CBPR addresses health from both positive and ecological perspectives.

- $\quad$ CBPR disseminates findings and knowledge gained to all partners. 
CBPR involves a long-term commitment by all partners.

Each of these points is discussed below.

\section{CBPR Involves Working with the Community as a Unit of Identity}

In CBPR, the community is regarded as having collective and individual identities. Units of identity, such as membership in a family, friendship network, or geographic neighborhood, are all socially constructed dimensions of identity, created and recreated through social interactions [41]. A community may be a defined geographic neighborhood or a geographically dispersed ethnic group, and share a sense of identity or emotional relation to other members, shared values and norms, mutual influence, common interests, and commitment to meeting shared needs [42]. One of the aims of CBPR is to identify and work with existing communities of identity, and to strengthen the sense of community through communal engagement to achieve desired health outcomes [43].

\section{CBPR Builds on Strengths and Resources within the Community}

Another goal of CBPR is to identify and build on community resources. This includes building on strengths and relationships that already exist within communities of identity, and supporting social structures and processes that improve community members' ability to work together to improve health outcomes [44]. Strengths include individual skills and assets of community members or 'human capital', existing networks or relationships defined by trust, cooperation and commitment or 'social capital'; and structures of influence and/or places of gathering within the community such as churches or schools [29, 4548].

\section{CBPR Involves Collaborative and Equal Involvement of all Partners in all Phases of the Research Process}

A unique aspect of CBPR is that it involves collaborative partnership with community members and/or organizations; within these partnerships, all involved parties participate as equal members and share control over all phases of the research process. This includes problem definition, data collection, interpretation of results, and application of the results to address community concerns [49]. Additionally, while communities contain many individual/organizational resources, outside resources may also prove to be beneficial. Hence, CBPR also involves individuals and groups from outside the immediate community, such as academia, health and human service organization representatives, community-based organizations, etc. These partnerships focus on identifying issues and concerns of the community, and creating and testing processes that enable all parties to participate in intervention efforts [50].

\section{CPBR Integrates Knowledge for Mutual Benefit of all Partners}

An important tenet of the CBPR method is that it seeks to build a broad information base within the plethora of health and well-being knowledge, and integrate that knowledge with intervention efforts to address specific concerns of the communities involved [51]. As a result, interventions are well-informed, and new understandings may surface as participants reflect after the interventions.

\section{CBPR Attends to Social Inequalities through a Co- Learning and Empowering Process}

CBPR emphasizes a reciprocal transfer of knowledge, skills, capacity, and power, which promotes a co-learning and empowering process [49]. Researchers aim to gain a local understanding of history, customs and common practices of community members, and community members acquire skills in conducting research [52]. In marginalized communities, CBPR researchers understand the importance of recognizing the inequalities between themselves and community participants, and the ways that these inequalities present in the communities may influence participation and influence in collective research and action [53]. Addressing these inequalities involves attention, respect and awareness of the knowledge of community members, and a strong emphasis on mutual decision-making, sharing knowledge and resources, and support among partners. This is an approach that is emphasized in CBPR [49].

\section{CBPR Involves a Cyclical and Iterative Process}

CBPR is a continuous process that includes partnership development and maintenance, community baseline assessment, problem definition, development of research methodology, data collection and analysis, interpretation of data, intervention development, policy implications, dissemination of results, applying intervention, improvement from the lessons learned, and developing measures for sustainability of intervention [54]. This feedback cycle helps inform and improve adaptability of interventions in CBPR [55]. 


\section{CBPR Addresses Health from both Positive and Ecological Perspectives}

CBPR addresses the concept of health from both a positive model of health that emphasizes physical, mental, and social well-being and an ecological model of health that addresses individual, interpersonal, social, economic, cultural, historical, and political factors in determinants of health and health behavior [56-58].

\section{CBPR Disseminates Findings and Knowledge Gained to all Partners}

When it comes to dissemination of results or findings, CBPR involves all partners involved, and proceeds in a language that is understandable and respectful, and "where ownership of knowledge is acknowledged" [50]. This means that contributions of participants are acknowledged, and where appropriate, developing coauthored publications [59].

\section{CBPR Involves a Long-Term Commitment by all Partners}

CBPR requires a long-term commitment by all the partners involved, since an extended period of time is required for establishing trust, developing the skills and infrastructure needed for research, and creating comprehensive interventions [41, 60]. This provides reassurance for communities that outside partners and researchers are committed to sustaining the interventions.

\section{Benefits and Perceived Drawbacks of Using the CPBR Model}

Although randomized control trials are highly effective with high internal validity, they are poorly translated to diverse environments. CBPR recognizes the importance of adaptation of research findings to multiple settings. By including community stakeholders in identifying community priorities and barriers, the model allows for practical intervention planning with high external validity [12]. Language use ties in closely with the issue of knowledge dominance in many interventions. CBPR aims to make changes in the research discourse, by shifting from language that encourages "research subject" or "targeting community members" to "research participant" and "community participation" and allowing for the opportunity to integrate novel, community-sourced ideas [12, 61]. Additionally, since standard research practice is characterized by universities' control of resources, budgets, and processes, it is often dominated by White academics and may reflect institutional biases against faculty of color or perpetuate the very inequalities academics aim to address [61]. However, faculty of color may actually connect more effectively with disenfranchised groups, and CBPR addresses this by promoting diverse research teams, including staff and students from the same ethnic minority population as the community. Another important issue addressed by the model is the sustainability issue for public health researchers. Even interventions that are highly effective during implementation may not successfully integrate with the community, as seen from follow up studies. One of the main tenets of CBPR is capacity training for community members in program implementation and research to help integrate the new program into community systems. While many programs push effective' interventions through hierarchical polices, they are often unsuccessful because of mistrust from community members. CBPR is based on community engagement and involvement, where community members are treated as valuable contributing members of the process. This approach fosters greater trust and enables most effective translation of research within diverse settings [12].

There are relatively few CBPR studies in the field of public health and this may be due to existing misconceptions about the approach. There is a misconception that every study needs to include all elements of CBPR. However, very often, full engagement with community members and comprehensive research will not be possible, due to lack of time or resources to incorporate all elements of CBPR. A more practical approach would be to uncover the type of CBPR needed to achieve the goals of their particular project, taking into account time and resource constraints. This can be achieved by engaging with community partners upfront. Furthermore, CBPR involves community members in the research process. Since these individuals are untrained in research methodology, the rigor of the CBPR method is often questioned. However, what is sacrificed in internal validity can be gained in increased external validity and greater adaptability of results to real-world settings. This method could also lead to stronger research, since some testing of interventions would not be possible without community support, and ultimately resulting in more sustainable and effective programs that are tailored to the community context and consistent with community priorities [62].

\section{CONCLUSION}

Finally, it is important to recognize that the increase in childhood obesity suggests a greater need to identify 
environmental influences rather than just biological/ individual influences. CBPR has great potential in framing change efforts on multiple levels, and is emerging as one of the most practical ways of addressing the issue on a large scale. Few CBPR interventions have addressed obesity, but the ones that have incorporated CBPR have shown noteworthy results. As the gaps in health outcomes continue to increase in a society that is both multicultural and multiethnic, CBPR is very important to help find sustainable solutions. Some of the benefits of CBPR approach are interventions with greater contextual and cultural centeredness, greater retention, and strengthened community capacity. Further steps in CBPR include the need for formal training in the process and increased availability to both academically-based researchers and community members. Additionally, articulating CBPR to the academic community as a method that is rigorous and unique, is paramount in engaging academic researchers on CBPR projects.

\section{ACKNOWLEDGEMENT}

This project was supported by the Agriculture and Food Research Initiative (AFRI) Grant no. 2012-6800119619 from the USDA National Institute for Food and Agriculture.

\section{REFERENCES}

[1] Ogden CL, Carroll MD, Kit BK, Flegal KM. Prevalence of obesity and trends in body mass index among US children and adolescents, 1999-2010. JAMA 2012; 307: 483-90. http://dx.doi.org/10.1001/jama.2012.40

[2] Fryar CD, Carroll, MD, Odgen CL. Prevalence of obesity among children and adolescents: United States, trends 1963-1965 through 2009-2010. Centers for Disease Control and Prevention; 2012. Available at: http://www.cdc.gov/nchs/ data/hestat/obesity_child_09_10/obesity_child_09_10.htm. Accessed September 13, 2012.

[3] Summerbell CD, Waters E, Edmunds LD, Kelly S, Brown T, Campbell KJ. Interventions for preventing obesity in children. Cochrane Database Syst Rev 2005; (3): CD001871.

[4] Doak CM, Visscher TL, Renders CM, Seidell JC. The prevention of overweight and obesity in children and adolescents: a review of interventions and programmes. Obes Rev 2006; 7: 111-36 http://dx.doi.org/10.1111/j.1467-789X.2006.00234.x

Flynn MA, McNeil DA, Maloff $B$, et al. Reducing obesity and related chronic disease risk in children and youth: a synthesis of evidence with 'best practice' recommendations. Obes Rev 2006; 7: 7-66.

http://dx.doi.org/10.1111/j.1467-789X.2006.00242.x

[6] Economos CD, Hyatt RR, Goldberg JP, et al. A community intervention reduces BMI z-score in children: shape up Somerville first year results. Obesity (Silver Spring) 2007; 15: 1325-36.

http://dx.doi.org/10.1038/oby.2007.155
[7] Bogart LM, Elliott MN, Uyeda K, Hawes-Dawson J, Klein DJ, Schuster MA. Preliminary health eating outcomes of SNaX, a pilot community-based intervention for adolescents. J Adol Health 2011; 48: 196-202.

http://dx.doi.org/10.1016/j.jadohealth.2010.06.004

[8] Hoelscher D, Andrew E, Springer A, et al. Reductions in child obesity among disadvantaged school children with community involvement: the Travis County CATCH Trial. Obesity (Silver Spring) 2010; 18: 36-44. http://dx.doi.org/10.1038/oby.2009.430

[9] Sanigorski AM, Bell AC, Kremer PJ, Cuttler R, Swinburn BA. Reducing unhealthy weight gain in children through community capacity-building: results of a quasi-experimental intervention program, Be Active Eat Well. Int J Obes 2008; 32: 1060-7.

http://dx.doi.org/10.1038/ijo.2008.79

[10] Krug E, Dahlberg LL, Mercy JA, Zwi AB, Lozano R. Violence - a global public health problem. In: World report on violence and health. Geneva, Switzerland: World Health Organization (WHO); 2002: 1-21.

[11] Israel BA, Coombe CM, Cheezum RR, et al. Communitybased participatory research: A capacity-building approach to policy advocacy aimed at eliminating health disparities. Am J Public Health 2010; 100: 2094-102. http://dx.doi.org/10.2105/AJPH.2009.170506

[12] Wallerstein N, Duran B. Community-based participatory research contributions to intervention research: the intersection of science and practice to improve health equity. Am J Public Health 2010; 100: 40-6. http://dx.doi.org/10.2105/AJPH.2009.184036

[13] Minkler $M$, Wallerstein N. Community-based participatory research for health. San Francisco, CA: Jossey-Bass Press; 2003.

[14] Israel BA, Schulz AJ, Parker EA, Becker AB. Review of community-based research: assessing partnership approaches to improve public health. Ann Rev Public Health 1988; 19: 173-202.

http://dx.doi.org/10.1146/annurev.publhealth.19.1.173

[15] Kumanyika SK. Environmental influences on childhood obesity: ethnic and cultural influences in context. Physio Behav 2008; 22: 61-70. http://dx.doi.org/10.1016/i.physbeh.2007.11.019

[16] de Wilde JA, van Dommelen P, Middelkoop BJ, Verkerk PH. Trends in overweight and obesity prevalence in Dutch, Turkish, Moroccan and Surinamese South Asian children in the Netherlands. Arch Dis Child 2009; 94: 795-800. http://dx.doi.org/10.1136/adc.2009.163709

[17] Morgen CS, Mortensen LH, Rasmussen M, Andersen AM, Sorensen $\mathrm{TI}$, Due P. Parental socioeconomic position and development of overweight in adolescence: longitudinal study of Danish adolescents. BMC Public Health 2010; 10: 520.

http://dx.doi.org/10.1186/1471-2458-10-520

[18] Sallis JF, Glanz K. The role of built environments in physical activity, eating, and obesity in childhood. Future Child 2006; 16: 89-108.

http://dx.doi.org/10.1353/foc.2006.0009

[19] Darmon N, Drewnowski A. Does social class predict diet quality? Am J Clin Nutr 2008; 87: 1107-17.

[20] Burns $C$. The vulnerable and the disadvantaged. Australian Econ Rev 2008; 41: 90-6. http://dx.doi.org/10.1111/j.1467-8462.2008.00489.x

[21] Wandel $M$, Råberg $M$, Kumar $B$, Holmboe-Ottesen $G$. Changes in food habits after migration among South Asians settled in Oslo: the effect of demographic, socio-economic and integration factors. Appetite 2008; 50: 376-85. http://dx.doi.org/10.1016/j.appet.2007.09.003 
[22] Minkler M. Linking science and policy through communitybased participatory research to study and address health disparities. Am J Public Health 2010; 100: S81-7. http://dx.doi.org/10.2105/AJPH.2009.165720

[23] Dallman MF, Pecoraro N, Akana SF, et al. Chronic stress and obesity: a new view of "comfort food". Proc Natl Acad Sci USA 2003; 100: 11696-701.

http://dx.doi.org/10.1073/pnas.1934666100

[24] Bleich S, Blendon R, Adams A. Trust in scientific experts on obesity: implications for awareness and behavior change. Obesity (Silver Spring) 2007; 15: 2145-56. http://dx.doi.org/10.1038/oby.2007.255

[25] Neumark-Sztainer D, Wall M, Guo J, Story M, Haines J, Eisenberg M. Obesity, disordered eating, and eating disorders in a longitudinal study of adolescents: how do dieters fare 5 years later? J Am Diet Assoc 2006; 106: 55968. http://dx.doi.org/10.1016/j.jada.2006.01.003

[26] Kelly B, Halford JC, Boyland EJ, et al. Television food advertising to children: a global perspective. Am J Public Health 2010; 100: 1730-6.

http://dx.doi.org/10.2105/AJPH.2009.179267

[27] Bell R, Berger C, Cassady D. Townsend M. Portrayals of food practices and exercise behavior in popular American films. J Nutr Educ Behav 2005; 37: 27-32. http://dx.doi.org/10.1016/S1499-4046(06)60256-X

[28] Coveney J. A qualitative study exploring socio-economic differences in parental lay knowledge of food and health: implications for public health nutrition. Public Health Nutr 2005; 8: 290-7. http://dx.doi.org/10.1079/PHN2004682

[29] Israel BA, Schulz AJ, Parker EA, Becker AB, Allen AJ III, Guzman JR. Critical issues in developing and following CBPR principles. In: Minkler $\mathrm{M}$, Wallerstein $\mathrm{N}$ ed. Community-based participatory research for health. $2^{\text {nd }}$ ed. San Francisco, CA: Jossey-Bass Press; 2008:49-66.

[30] Molnar BE, Gortmaker SL, Bull FC, Buka SL. Unsafe to play? Neighborhood disorder and lack of safety predict reduced physical activity among urban children and adolescents. Am J Health Promot 2004; 8: 378-86.

http://dx.doi.org/10.4278/0890-1171-18.5.378

[31] Borraccino A, Lemma $P$, lannotti RJ, et al. Socioeconomic effects on meeting physical activity guidelines: comparisons among 32 countries. Med Sci Sports Exerc 2009; 41: 749-56. http://dx.doi.org/10.1249/MSS.0b013e3181917722

[32] Chomitz VR, McGowan RJ, Wendel JM, et al. Healthy living Cambridge kids: a community-based participatory effort to promote healthy weight and fitness. Obesity (Silver Spring) 2010; 18: 45-53.

http://dx.doi.org/10.1038/oby.2009.431

[33] French SA, Story M, Neumark-Sztainer D, Fulkerson JA, Hannan P. Fast food restaurant use among adolescents: associations with nutrient intake, food choices and behavioral and psychosocial variables. Int J Obes 2001; 12: 1823-33. http://dx.doi.org/10.1038/sj.ijo.0801820

[34] McLeroy KR, Bibeau D, Steckler A, Glanz K. An ecological perspective on health promotion programs. Health Educ $Q$ 1988; 15: 351-77. http://dx.doi.org/10.1177/109019818801500401

[35] Sallis JF, Owen N, Fisher, EB. Ecological models of health behavior. In: Glanz K, Rimer BK, Viswanath K ed. Health behavior and health education: theory, research and practice. $4^{\text {th }}$ ed. San Francisco, CA: Jossey-Bass Press; 2008:435-485.

[36] Stokols D. Translating social ecological theory into guidelines for community health promotion. Am J Health Promot 1996; 10: $282-98$

http://dx.doi.org/10.4278/0890-1171-10.4.282
[37] Fleury J, Lee SM. The social ecological model of physical activity in African American women. Am $\mathrm{J}$ Community Psychol 2006; 37: 129-40. http://dx.doi.org/10.1007/s10464-005-9002-7

[38] Krug E, Dahlberg LL, Mercy JA, Zwi AB, Lozano R. Violence - a global public health problem. In: World report on violence and health. Geneva, Switzerland: World Health Organization (WHO); 2002: 1-21.

[39] Wagener DK, Williams DR, Wilson PM. Equity and environmental health: data collection and interpretation issues. Toxicol Industr Health 1993; 9: 775-95.

[40] Herbert CP. Community-based research as a tool for empowerment: the Haida Gwaii diabetes project example. Can J Public Health 1996; 87: 109-12.

[41] Hatch J, Moss N, Saran A. Presley-Cantrell L and Mallory C, Community research: partnership in black communities. Am J Prev Med1993; 9: 27-31.

[42] Steuart GW. Social and cultural perspectives: community intervention and mental health. Health Educ Quart 1993; 1: 99-111.

[43] Israel BA, Cbeckoway B, Schulz A, Zimmerman M. Health education and community empowerment: conceptualizing and measuring perceptions of individual, organizational, and community control. Health Educ Q 1994; 21: 149-70. http://dx.doi.org/10.1177/109019819402100203

[44] McKnight J. Regenerating community. Social Policy 1987; 17: 54-8.

[45] McKnight JL. Politicizing health care. In: Conrad P, Kern R, ed. The sociology of health and illness: Critical perspectives. New York: St. Martin's Press; 1994: 437-41.

[46] Coleman J. Social capital in the creation of human capital. Am J Sociol 1988; 94: 95-120. http://dx.doi.org/10.1086/228943

[47] Israel BA, Schurman SJ. Social support, control and the stress process. In: Glanz K, Lewis FM, Rimer BK, ed. Health behavior and health education: theory, research and practice. San Francisco, CA: Jossey-Bass Press; 1990: 179205.

[48] Berger PL, Neuhaus RJ. To empower people: the role of mediating structures in public policy. In: Berger PL, Neuhaus $\mathrm{RJ}$, ed. American enterprise institute for public policy research. Washington, D.C: Aei Press; 1977.

[49] Bishop R. Initiating empowering research? New Zeal J Educ Stud 1994; 29: 175-88.

[50] Bishop R. Addressing issues of self-determination and legitimation in Kaupapa Maori research. In: Webber B, ed. Research perspectives in Maori education. Wellington, New Zealand: Council for Educational Research; 1996: 143-60.

[51] Green LW, George MA, Daniel M, et al. Study of participatory research in health promotion. Vancouver, Canada: University of British Columbia Press, Vancouver; 1995.

[52] Elden M, Levin M. Cogenerative learning. In: Whyte WF, ed. Participatory action research. Newbury Park, CA: Sage Press; 1991: 127-42.

[53] Blankenship KM, Schulz AJ. Approaches and dilemmas in community-based research and action. In: Annual Meeting of the Society for the Study of Social Problems 1996; New York, NY.

[54] Altman DG. Sustaining interventions in community systems: On the relationship between researchers and communities. Health Psychol 1995; 14: 526-36. http://dx.doi.org/10.1037/0278-6133.14.6.526

[55] Fawcett SB, Paine-Andrews A, Francisco VT, et al. Empowering community health initiatives through evaluation In: Fetterman DM, Kaftarian SJ, Wandersman A, ed. Empowerment evaluation: Knowledge and tools of selfassessment and accountability. Thousand Oaks, CA: Sage Press; 1996: 161-187. 
[56] Constitution of the World Health Organization (WHO) $45^{\text {th }}$ ed. http://www.who.int/governance/eb/constitution/en/ Published October 2006. Accessed October 1, 2012.

[57] Kelly MP, Davies JK, Charlton BG. A modern problem or a postmodern solution? In: Davis JK, Kelly MP, ed. Healthy cities: Research and practice. New York: Routledge Press; 1993: 159-67.

[58] Brown ER. Community action for health promotion: a strategy to empower individuals and communities. Int J Health Serv $1991 ; 21: 441-56$. http://dx.doi.org/10.2190/AKCP-L5A4-MXXQ-DW9K

[59] Schulz AJ, Israel BA, Selig SM, Bayer IS, Griffin CB. Development and implementation of principles for community-based research in public health. In: MacNair $\mathrm{RH}$, ed. Research strategies for community practice. New York: Haworth Press; 1998: 83-110.
[60] Israel BA, Schurman SJ, Hugentobler MK. Conducting action research: relationships between organization members and researchers. J Appl Behav Sci 1992; 28: 74-101. http://dx.doi.org/10.1177/0021886392281008

[61] Horowitz CR, Robinson M, Seifer S. Community-based participatory research from the margin to the mainstream: are researchers prepared? Circulation 2009; 119: 2633-42. http://dx.doi.org/10.1161/CIRCULATIONAHA.107.729863

[62] Bogart LM, Uyeda K. Community-based participatory research: partnering with communities for effective and sustainable behavioral health interventions. Health Psychol 2009; 28: 391-3. http://dx.doi.org/10.1037/a0016387

Received on 01-10-2014

Accepted on 21-10-2014

Published on 27-11-2014

http://dx.doi.org/10.6000/1929-4247.2014.03.04.3

(C) 2014 Kumar et al.; Licensee Lifescience Global.

This is an open access article licensed under the terms of the Creative Commons Attribution Non-Commercial License (http://creativecommons.org/licenses/by-nc/3.0/) which permits unrestricted, non-commercial use, distribution and reproduction in any medium, provided the work is properly cited. 